\title{
Moonmilk as a human and veterinary medicine: evidence of past artisan mining in caves of the Austrian Alps
}

\author{
Christoph Spötl \\ Institute of Geology, University of Innsbruck, Innrain 52, 6020 Innsbruck, Austria
}

\begin{abstract}
The use of moonmilk for medical and other purposes in the Alps is documented since the $16^{\text {th }}$ century. This article reviews speleological reports and sparse historical accounts about the extraction of moonmilk from 18 caves in the Eastern Alps of Austria in an artisan mining style. One such example from a cave in Tyrol is documented in detail, where moonmilk was mined until the beginning of the $20^{\text {th }}$ century and which, due to its remote location, uniquely preserved traces of both the mining and processing style.
\end{abstract}

Keywords: $\quad$ speleothem, moonmilk, mining, medical use, history, Alps, Austria

Received 8 January 2018; Revised 26 March 2018; Accepted 27 March 2018

Citation: Spötl C., 2018. Moonmilk as a human and veterinary medicine: evidence of past artisan mining in caves of the Austrian Alps. International Journal of Speleology, 47 (2), 127-135. Tampa, FL (USA) ISSN 0392-6672 https://doi.org/10.5038/1827-806X.47.2.2174

\section{INTRODUCTION}

One of the most widespread types of speleothems in caves worldwide is moonmilk. This white, water-rich material can be mineralogically complex (Hill \& Forti, 1997), but mostly consists of microscopic fibres of calcite (e.g., Borsato et al., 2000; Richter et al., 2008; Cailleau et al., 2009). Recent studies have shown that moonmilk contains a wide variety of microorganisms including bacteria, fungi and archaea (e.g., Barton \& Jurado, 2007; Engel et al., 2013; Reitschuler et al., 2015, 2016; Maciejewska et al., 2016). These microbial communities are thought to play a key role in carbonate precipitation (Blyth \& Frisia, 2008; Maciejewska et al., 2017).

Another aspect that sets moonmilk apart from other types of cave deposits is its use as a veterinary and human medicine in former centuries. One of the oldest historical documents is Konrad Gesner's report (1555) about Montmilchloch near Lucerne, Switzerland, where moonmilk was extracted by locals and used as a remedy. Scattered reports exist about this practice in other regions of Central Europe and in particular in the Alps (e.g., Shaw, 1992). Moonmilk at that time was known as Lac lunae or Nihilum album, although dozens of other synonyms exist (Heller, 1966). Nihilum album is in fact the old pharmaceutical term of zinc oxide (e.g., Hahnemann, 1798; Richter, 1832; Moll, 1839). Its colour and powdery appearance are similar to (dehydrated) moonmilk. Zinc oxide is known for its antibacterial and antifungal properties (e.g., Sawai et al., 1995; Sawai \& Yoshikawa, 2004; Padmavathy
\& Vijayaraghavan, 2008) and, for hundreds of years, was widely used to treat a variety of skin conditions and eye diseases (e.g., Lonitzer, 1578) until the discovery of antibiotics in the first half of the $20^{\text {th }}$ century. On the other hand, it is still unclear to what extent moonmilk has pharmaceutical effects. In fact, most previous authors have supposed that it has little or no such effect and was an intended or unintended substitute for zinc oxide (e.g., Kyrle, 1923; Binder, 1963; Trimmel, 1968; Reinbacher, 1994).

Interestingly, despite a large number of mostly concise reports mentioning the use (or abuse) of moonmilk, little systematic research has been done, the etymology of this peculiar term being a notable exception (Reinbacher, 1994, 1995). Here, I review the sparse accounts and hints about mining activities for moonmilk in caves of the Eastern Alps of Austria and document one such cave which, due to its difficult access, uniquely preserved traces of former moonmilk extraction including relics of the primitive tools and techniques used.

\section{MOONMILK CAVES IN THE ALPS}

There are hundreds if not thousands of caves in the Alps containing moonmilk, either as an actively forming, i.e. soft deposit, and/or as (partly) dehydrated, hard or crumbly crusts coating cave floors, walls and ceilings or other speleothems. Moonmilk deposits are commonly between a few millimetres and several centimetres thick, but reach up to about $1 \mathrm{~m}$ in places (Pavuza, pers. comm., 2018). These formations occur 
in a variety of geometries, from planar deposits to mammillary and stalactitic forms. The vast majority of these deposits consists of calcite. A systematic study in the Southern Alps (Borsato, 1996) showed that moonmilk is most abundant in caves between about $1,400 \mathrm{~m}$ a.s.1. and the upper limit of the timberline (i.e., close to 2,000 $\mathrm{m}$ a.s.1.). Moonmilk is rare in the twilight zone close to the entrance, and locally also forms subaqueously in shallow pools (so-called cottonballs).

The German expression for moonmilk in the western part of the Alps (mainly Switzerland) is Montmilch, while the term Bergmilch is common in the eastern part (Austria). The latter term is etymologically rather young and first appeared at the end of the $18^{\text {th }}$ century (Heller, 1966, p. 56; Reinbacher, 1995, p. 19). In previous centuries, the synonym Nix was widely used and is still in use in Austria. This word is derived from Nihilum album and appears in historical accounts since the $17^{\text {th }}$ century. The oldest mention to my knowledge is in a report from AD 1650 by the administrator at the guardianship court in Werfen (Pflegsverwalter in German), Kaspar Glück, about Scheukofen, a cave in the province of Salzburg, where moonmilk was mined by locals (see below). The word Nix is part of common cave names, e.g., Nixloch, Nixhöhle or Nixofen. Another German name indicative of moonmilk deposits is Galmei (e.g., Galmeiloch, Galmeihöhle). Galmei is the old miners' term for zinc oxide found associated with ore deposits and points to the already mentioned confusion between moonmilk and this oxide mineral that was used as a pharmaceutical. Other German synonyms for moonmilk used in the Eastern Alps are Kreide (e.g., Kreidelucke) and Schotten (e.g., Schottenloch).

\section{HISTORICAL REPORTS ABOUT MOONMILK MINING IN AUSTRIAN CAVES}

Figure 1 provides an overview of caves in the Austrian Alps whose (German) names indicate the presence of moonmilk. Highlighted are those sites where either written reports or in-situ observations of moonmilk mining exist. Below I summarize the available information about those caves where mining evidence is rather compelling, starting with the sites in the west and grouped according to the Austrian provinces, whereby the westernmost site and the only one in the province of Tyrol (Nixofen, 1264/9) will be discussed separately in the next section. The number in parentheses behind the cave name is the cave number based on the Austrian cave register.

\section{Salzburg}

Nixloch $(1331 / 17)$ is a small, $32 \mathrm{~m}$-long cave near Weißbach bei Lofer, whose entrance lies at $800 \mathrm{~m}$ a.s.1. Czoernig-Czernhausen (1926, p. 126), Waldner (1942, p. 3) and Klappacher \& Knapczyk (1977, p. 181) reported that the moonmilk deposits from this cave were used by locals as animal medicine.

Scheukofen $(1335 / 4)$, a $1,400 \mathrm{~m}$-long cave that opens at $740 \mathrm{~m}$ a.s.1. in the Salzach Valley on the eastern flank of Hagengebirge, is an important site where moonmilk, present in the side chambers of the large entrance hall, was mined until the $19^{\text {th }}$ century (Klappacher \& Knapczyk, 1979, p. 143). The report from AD 1650 by the administrator at the guardianship court in Werfen mentioned above is not just the oldest known official document about primitive mining of moonmilk in the Eastern Alps; in spite of its shortness, it also gives some hints

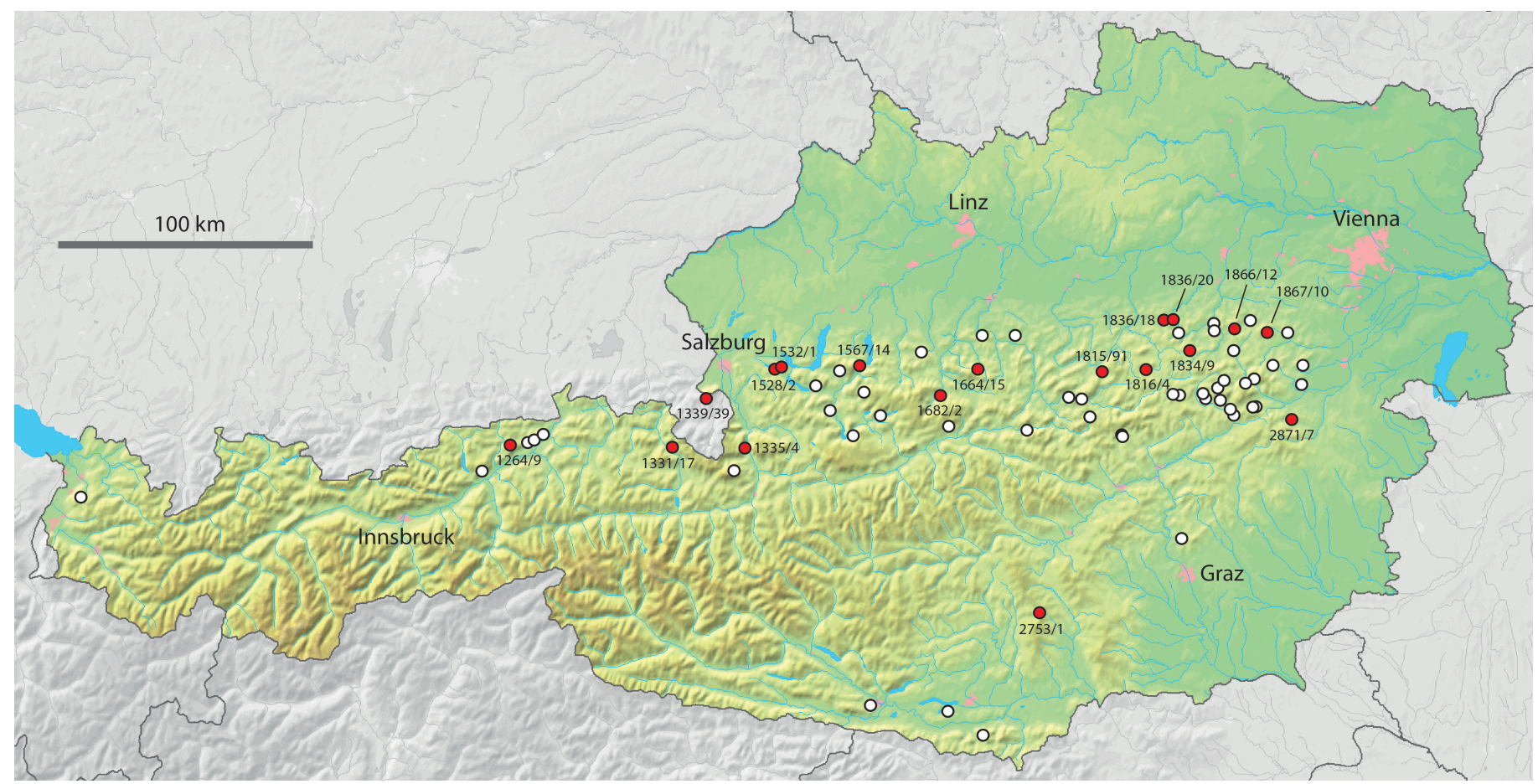

Fig. 1. Map of Austria showing caves whose names contain the German word Bergmilch, Nix, Kreide, Galmei or Schotten and hence indicate the presence of moonmilk (white dots). Many more caves in this country contain moonmilk but not as part of their name. Sites with evidence of former mining of moonmilk based on historical accounts or in-situ observations are shown by red dots including their cave register number. Nixloch bei Hallthurm (1339/39) is located in Bavaria close to the Austrian border. Nixofen (1264/9), discussed in detail in this article, is the only currently known moonmilk mine in the western part of Austria. Cave data based on Spelix database (https://www.spelix.at). Basemap: https://commons. wikimedia.org/wiki/File\%3AAustria topographic map.png. 
about the style of these activities. Importantly, the cave and its moonmilk deposits were apparently unknown to the authorities who became suspicious as a result of folk stories, e.g. about treasures in this cave guarded by mountain trolls. On behalf of the archiepiscopal counsellor, the administrator made inquiries about this cave. He learned that crowds of people, both citizens and foreigners, knew about the cave and had entered it (some of them secretly). They removed a white substance from the cave and sold it to the local pharmacist (Vierthaler, 1816, p. 181). The document even reports how much money these people made per sold pound: the pound moonmilk was sold for 4 Kreuzer. A common way to compare historical prices to present-day currencies is to take a common commodity for which there are records of prices over the centuries. E.g. in 1650 the price for one pound (half a kilogram) of beef in Vienna was about 3 Kreuzer (http://www.habsburger.net/en/glossary/ what-could-viennese-buy-their-kreuzer-and-gulden). In the $17^{\text {th }}$ century 1.4 litres of wine costed between 10 and 16 Kreuzer in Linz (Rumpl, 1962, p. 339).

While no details are given about the style of mining in Scheukofen, it is interesting that the administrator had trouble finding people who were ready to provide information about the cave and its location. Several witnesses disappeared or pretended not to know the whereabouts of this cave (Klappacher \& Knapczyk, 1979 , p. 147). Only an old miner told the administrator that the last time he visited the cave was some fifty years ago, when he searched for ore but only found two skulls. The overall impression this report from the $17^{\text {th }}$ century conveys is that several people knew about the cave and its moonmilk but that this information was kept secret.

Schotterloch $(1528 / 2)$ is a short, only $12 \mathrm{~m}$-long cave at $830 \mathrm{~m}$ a.s.1. east of Fuschl. Waldner (1942, p. 8) reported that locals were still visiting this cave to obtain moonmilk in the 1940s, which was being used by farmers to cure intestinal diseases in cattle. Interestingly, there is no mention of these activities in other speleological accounts, e.g. CzoernigCzernhausen (1926, p. 47) or Klappacher (1992, p. 338).

Another moonmilk-bearing cave is Nixloch (1532/1) located $2.5 \mathrm{~km}$ northeast of Schotterloch on the Drachenwand (1,100 $\mathrm{m}$ a.s.1.). While neither CzoernigCzernhausen (1926, p. 45-46) nor Waldner (1942, p. 3) mentioned traces of mining, Klappacher (1992, p. 346) stated that moonmilk was extracted from this cave for centuries.

\section{Upper Austria}

Nixlucke im Annerlgraben $(1567 / 14)$ is a 150 m-long cave located west of Ebensee, whose entrance opens at $755 \mathrm{~m}$ a.s.1. Franz Kraus, an eminent Austrian speleologist and author of the first book on cave science published in German (Kraus, 1894), visited this cave in 1879 guided by an old man whom he referred to as Nixgräber ("moonmilk digger"). Three other men joined them; one of them was a licenced local mountain guide. It is telling that this person had heard about the cave but did not know its location. Kraus described the difficult access to this cave, its narrow entrance and the presence of a wooden ladder which was installed by the Nixgräber seven years earlier (Kraus, 1880, p. 79).

Kreidelucke $(1682 / 2)$ is a well-known cave rich in moonmilk, located near Hinterstoder. It has a total length of $1,042 \mathrm{~m}$ and opens at $580 \mathrm{~m}$ a.s.1. Hauenschild (1866, p. 361-362) organised an expedition into the cave and described traces of moonmilk extraction, including deep holes left by mining, steps carved into the moonmilk, and old wooden ladders and inscriptions. He mentioned that moonmilk was sold also to cattle dealers who added it to the forage to make farm animals, in particular horses, look stronger. Gressel et al. (1951) studied the cave and its sediments and noticed clear traces of moonmilk mining. They were told by an informant that moonmilk was used until recent times as a raw material for the production of chamotte.

Nixlucke $(1664 / 15)$ is a cave on the northern side of Sengsengebirge that opens at $1,470 \mathrm{~m}$ a.s.1. The walls of this $36 \mathrm{~m}$-long cave are partly covered by moonmilk and show clear cut marks that were created during the former extraction of this material (Weichenberger, 2000, p. 134).

\section{Lower Austria}

Southeast of Göstling, Krähenloch (1815/91) opens at $760 \mathrm{~m}$ a.s.1. Hartmann \& Hartmann (1985, p. 125) reported traces of moonmilk extraction in this 100 m-long cave.

Galmeiloch (1816/4), $226 \mathrm{~m}$ long and located at $1,346 \mathrm{~m}$ a.s.1. WNW of Mariazell was also visited in former times in order to extract moonmilk. Waldner (1942, p. 5-6) reported that this cave was still being visited by people looking for moonmilk and locals told him that moonmilk was commonly used to clean cutlery. Hartmann \& Hartmann (1985, p. 172) mentioned the presence of wooden ladders as evidence of the primitive mining activity.

WSW of Frankenfels is another former Nixbergwerk ("moonmilk mine"), Mariannenhöhle (1836/18, $437 \mathrm{~m}, 636 \mathrm{~m}$ a.s.1.). In addition to clear traces of moonmilk extraction, Waldner (1942, p. 4) reported black characters made by the diggers using torches, whereby crossed strokes and scissors-like signs were the most common ones.

Nixhöhle $(1836 / 20)$ is a show cave located WSW of Frankenfels that is $1,410 \mathrm{~m}$ long and opens at 556 $\mathrm{m}$ a.s.1. According to locals this cave was visited by "moonmilk diggers" who carried the material to Mariazell and probably sold it there (Waldner, 1942, p. 4). Hartmann \& Hartmann (1982, p. 74) also mentioned traces of moonmilk mining, and the up to $1 \mathrm{~m}$ deep cuts in the moonmilk deposit were later made in the course of the development to a show cave (Pavuza, pers. comm., 2018).

The eponymous Nixhöhle (1834/9, 73 m long, 695 $\mathrm{m}$ a.s.1.) SSW of Türnitz was a moonmilk mine whose thick deposits show clear traces of extraction of this material (Waldner, 1942, p. 4; Hartmann \& Hartmann, 1982, p. 37).

Stadelbauernhöhle $(1866 / 12)$ is $70 \mathrm{~m}$ long and its entrance opens at $860 \mathrm{~m}$ a.s.1. south of the village 
Traisen. Waldner (1942, p. 5) reported abundant traces of mining activity and found remnants of old mining tools on the floor. Interestingly, the local farmers did not know about this cave and its moonmilk deposits, and nobody was able to provide information about the cave. Waldner did not report the name of the cave, but it is undoubtedly Stadelbauernhöhle (cf. Hartmann \& Hartmann, 1982, p. 129).

Another cave where moonmilk was found and used in the past is Nixofen (1867/10), a 34 m-long cave located at $840 \mathrm{~m}$ a.s.1., NNW of Gutenstein. Hartmann \& Hartmann (1982, p. 160) referred to it as an old Nixbergwerk.

The easternmost cave with clear traces of moonmilk extraction is Hermannshöhle (2871/7) at Kirchberg am Wechsel. This $4.4 \mathrm{~km}$-long labyrinth cave has long been known and opens at $620 \mathrm{~m}$ a.s.1. Jäger (1873, p. 250) reported that tests had shown that the dazzling white speleothems (which include moonmilk) can be used in the production of various things including soda water, paper and Gutta-percha. He quoted a price of 3 Gulden per $50 \mathrm{~kg}$ which is quite inexpensive when compared to other products and services at that time (Mrkos, 1997). Although there are traces of moonmilk mining at Weiße Kluft and near the Teich (Ilming, 1973) as well as above Dietrichshalle (Plan, pers. comm., 2018), the extracted volume was apparently small. Topitz (1974, p. 200) reported that local farmers used this moonmilk to prepare eyewashes.

\section{Carinthia}

The only site currently known in the southern part of Austria where moonmilk was extracted is Nixlucke (2753/1) near Klippitztörl. According to an old report, local farmers frequently went into this sub-horizontal $250 \mathrm{~m}$-long cave, whose entrance is located at 1,545 $\mathrm{m}$ a.s.1., and obtained moonmilk that they used as veterinary medicine (Reiner, 1857, p.145). Several inscriptions can be found in the cave, some dating back to the $18^{\text {th }}$ century. According to Waldner (1942, p. 3) this cave was visited more frequently in past centuries than in recent times.

\section{Bavaria (Germany)}

One site close to the Austrian border SSW of Salzburg is Nixloch bei Hallthurm (1339/39), which opens at $723 \mathrm{~m}$ a.s.1. and is $163 \mathrm{~m}$ long. According to Waldner (1942, p. 2), this cave was still visited by "moonmilk diggers" during the first half of the $20^{\text {th }}$ century.

\section{CASE STUDY: NIXOFEN}

The only cave where moonmilk was extracted in the western part of Austria and probably one of the best-preserved sites in the Austrian Alps is Nixofen $(1264 / 9)$ in Brandenberg in Tyrol (Fig. 1). It opens at $1,283 \mathrm{~m}$ a.s.1. on a steep north-facing slope (Fig. 2) that can only be accessed during snow- and ice-free conditions. Due to its remote location it is rarely visited, even by local cavers. The cave developed along the intersection of a fault and a bedding plane

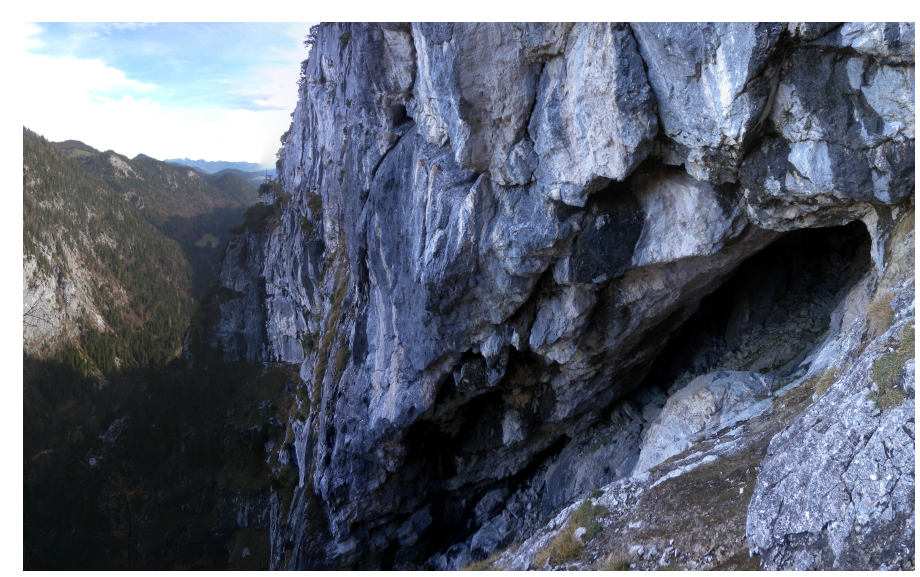

Fig. 2. Entrance to Nixofen (right), view towards East.

in thick-bedded Triassic limestone and has a simple, slanted geometry with the rear part being the highest (Fig. 3). Moonmilk is abundant in the middle and rear parts of the cave and comprises soft, sheetlike deposits typically $10-20 \mathrm{~cm}$ in thickness and moonmilk stalactites and columns that reach up to 2 $\mathrm{m}$ in length and up to about half a meter in diameter (Fig. 4A)

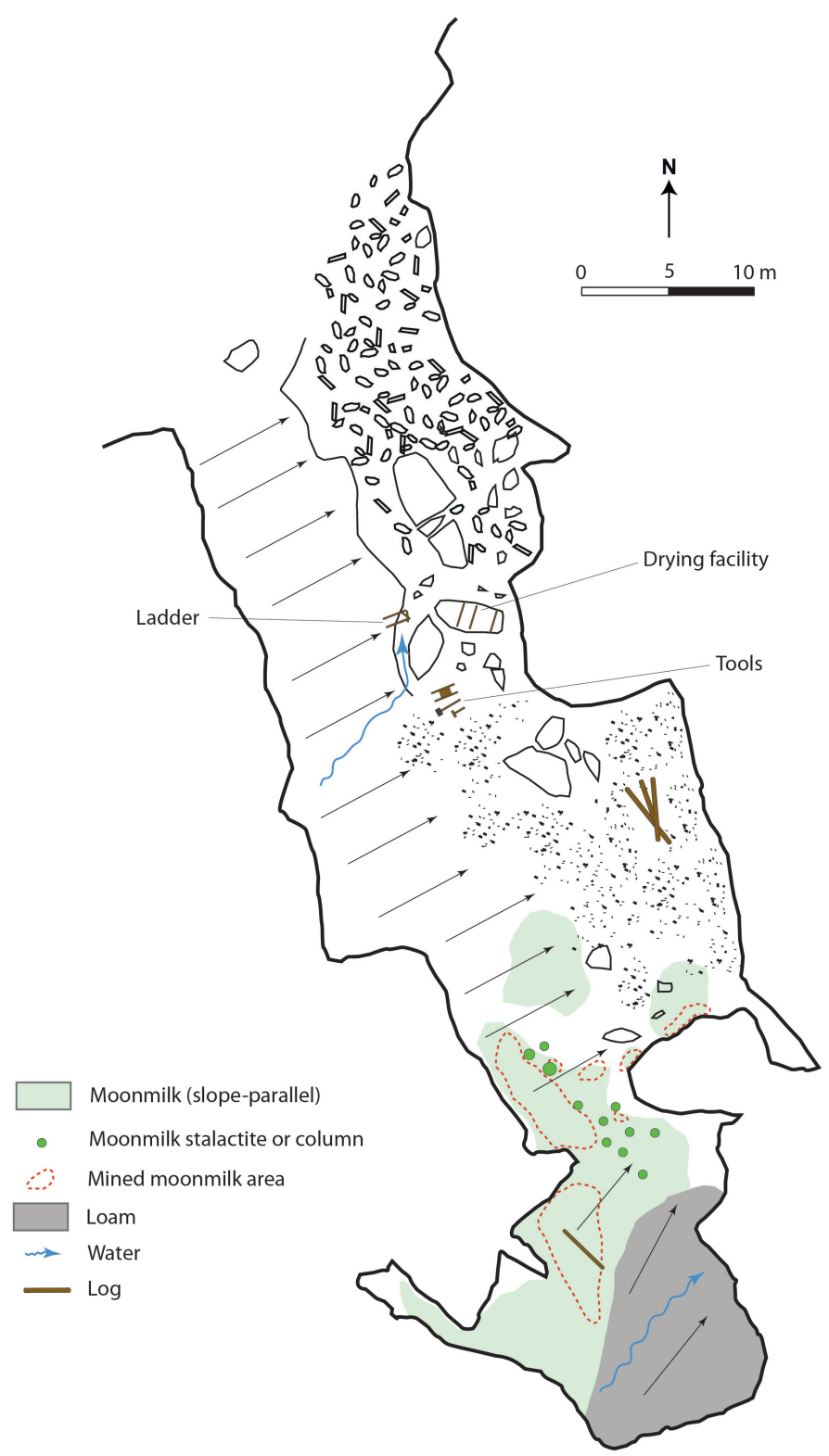

Fig. 3. Plan view of Nixofen showing the distribution of moonmilk both mined and still present. 
This Nixbergwerk is unique in the sense that it contains well-preserved traces of moonmilk mining as well as the remnants of primitive tools and devices used for mining and processing of moonmilk. Mining traces are found primarily in the rear part of the cave and show short linear features indicating that some sort of hoe was used to chop off moonmilk (Figs. 4B4D). The miners proceeded in a rather systematic manner and mined the moonmilk from below, working their way up the slope in the rear part of the cave. Close inspection of the hoe marks shows that they have since been overgrown by new moonmilk forming a layer up to about half a centimetre in thickness (Fig. 4E). The innermost part of the cave is still fairly pristine and contains white moonmilk up to $40 \mathrm{~cm}$ thick, indicating that the operation had ceased before all the moonmilk was extracted. The 10-20 cm thick moonmilk deposit on the inclined slope of the cave was the primary target of the miners, but at some places they also tried thick stalactites as shown by hoe marks (Fig. 4F). These moonmilk stalactites consist of partly dehydrated moonmilk that was apparently more difficult to mine than the soft variety. On the steep slope the miners made narrow horizontal terraces up to a few meters long in order to better access the moonmilk and because moonmilkcovered slopes are slippery.

Wooden tools are still preserved in the middle part of the cave (Fig. 5A) and in two places there are also rotten logs and wooden sticks that were obviously transported into the cave. The tools comprise (a) a wooden barrow (mortar trough) to be carried by two people, which was apparently used to transport the wet moonmilk to the flat middle part of the cave where is was processed, (b) a wooden tray, again probably used to transport moonmilk (has meanwhile
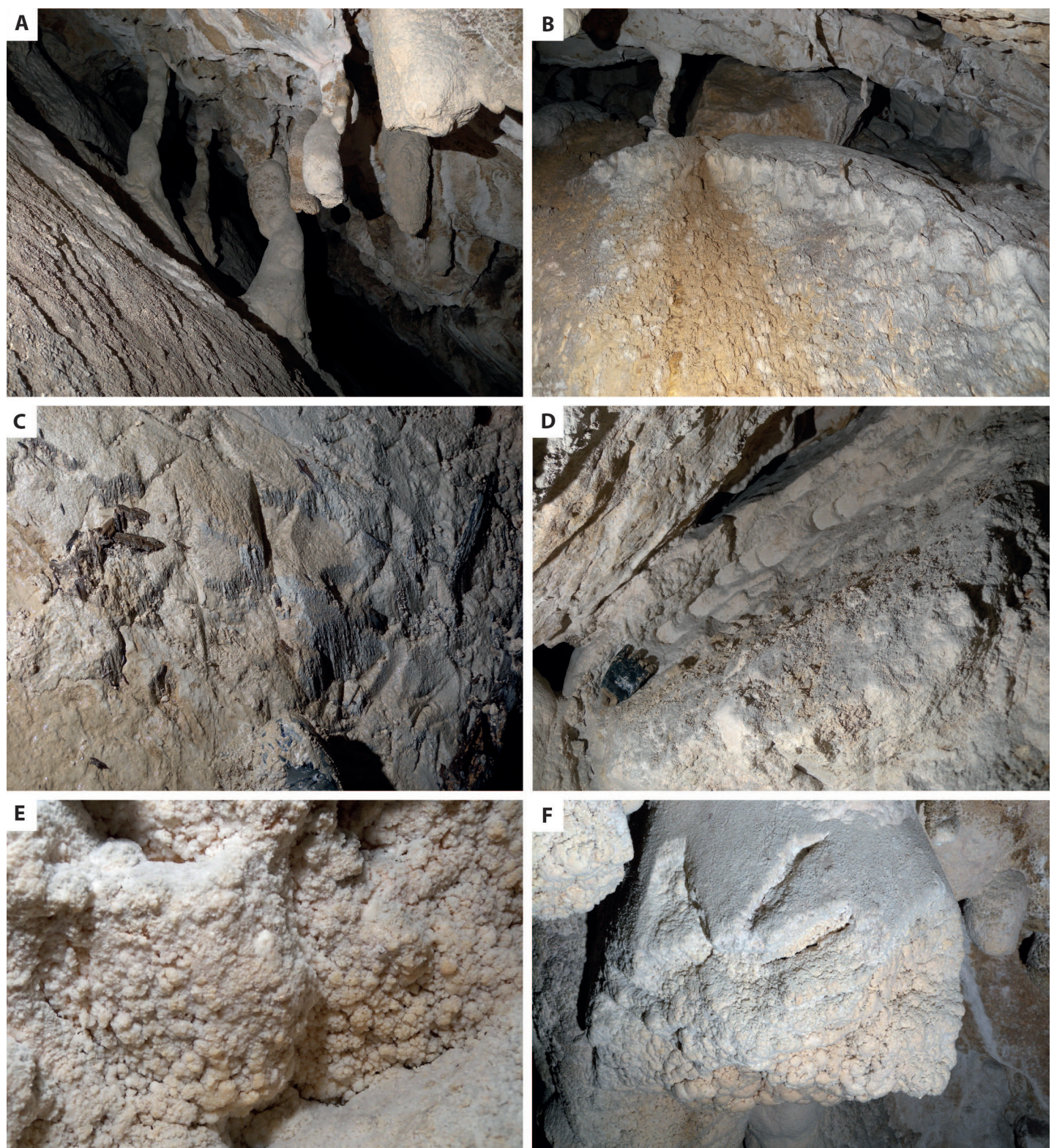

Fig. 4. A) Moonmilk columns and stalactites in the rear part of Nixofen. The column in the centre is almost $2 \mathrm{~m}$ tall; B) Sheet-like moonmilk (view upslope), which has largely been extracted except for the uppermost part. Width of image about $4 \mathrm{~m}$; C) Close-up of slope just beneath (B) showing hoe marks at the base of the former moonmilk deposit and traces of old wood fragments. Width of image about $0.5 \mathrm{~mm}$; D) Lateral hoe marks produced by a tool with a round edge. The entire deposit was mined exposing the bedrock underneath (white area in the foreground). Glove for scale; E) Close-up of (D) showing newly formed moonmilk covering the hoe marks. Width of image about $20 \mathrm{~cm}$; F) Hoe marks at the base of a moonmilk stalactite partly overgrown by new moonmilk. Width of image about $0.7 \mathrm{~m}$. 
disappeared), (c) a spade, (d) a wooden mallet and (e) a wooden ladder (Fig. 5B). Previously, an old hobnail leather boot was also found there. Interestingly, the shoe was rather small (about European size 37, i.e. about $23 \mathrm{~cm}$ long: Krejci et al., 1982). Of particular interest are the remains of a primitive facility to process mined moonmilk. A breakdown block with a flat inclined surface was used to dry moonmilk formed into hand-sized balls. For this purpose, vertical holes were drilled into the rock in order for short wooden sticks to hold horizontal wooden sticks that acted as shelves. This wooden structure is still preserved in the cave and the fact that these sticks are not rotten demonstrates that this spot was well selected by the miners to dry moonmilk. A photograph taken in 1977 still shows several moonmilk balls on these shelves (Fig. 5C) indicating that the mine was abandoned in a somewhat disorganized manner. The moonmilk balls have since been removed by occasional visitors and a few can still be found in private collections (Fig. 5D).

No historical documents exist about this Nixbergwerk and it was apparently forgotten. Georg Mutschlechner, the doyen of the mining history in Tyrol who had searched for past mining activity in Brandenberg did not mention this cave (Mutschlechner, 1975). According to Georg Auer (Brandenberg, pers. comm., 2017), the critical information for the re-discovery came from an old local (Josef Hintner, born in 1887) who saw the cave at the age of 14 , i.e. at the beginning of the $20^{\text {th }}$ century, when it was still in operation. In his old days he still remembered how to reach the cave and in 1977 Georg Auer and four other locals found it after a long search and took the first photographs.

The style of moonmilk mining in Nixofen suggests a multi-annual operation restricted to the summer/ fall season when this site could be accessed safely. Very few people probably knew about this activity and the authorities had no information about it. Due to the lack of written and oral documentation we can only speculate that the miners worked in this Nixbergwerk for short intervals, possibly slept in the cave, processed a batch of moonmilk balls and then left the cave with rucksacks full of dried moonmilk balls. The final product was most likely sold to a pharmacy. Back in the $19^{\text {th }}$ century, the closest one was located in Rattenberg in the Inn Valley to the south of the cave, which is approximately a $20 \mathrm{~km}-$ long hike (depending on the route).

The amount of moonmilk extracted from Nixofen is difficult to assess. Using the conservative assumption of an average thickness of the deposit of $10-15 \mathrm{~cm}$, the cave survey suggests that between 4 and $7 \mathrm{~m}^{3}$ of wet moonmilk was mined in total. Given the small dimensions of the drying facility (and the unknown time required to dehydrate the moonmilk so that it could be transported and sold - likely months), this volume of mined moonmilk suggests that the Nixbergwerk was in (seasonal) operation for decades. The precise timing and reason for its abandonment are unknown, but the available information and insitu observations point to an unplanned end early during the $20^{\text {th }}$ century, possibly related to the fact that most men were drafted into the Austrian army during WWI and many never returned.
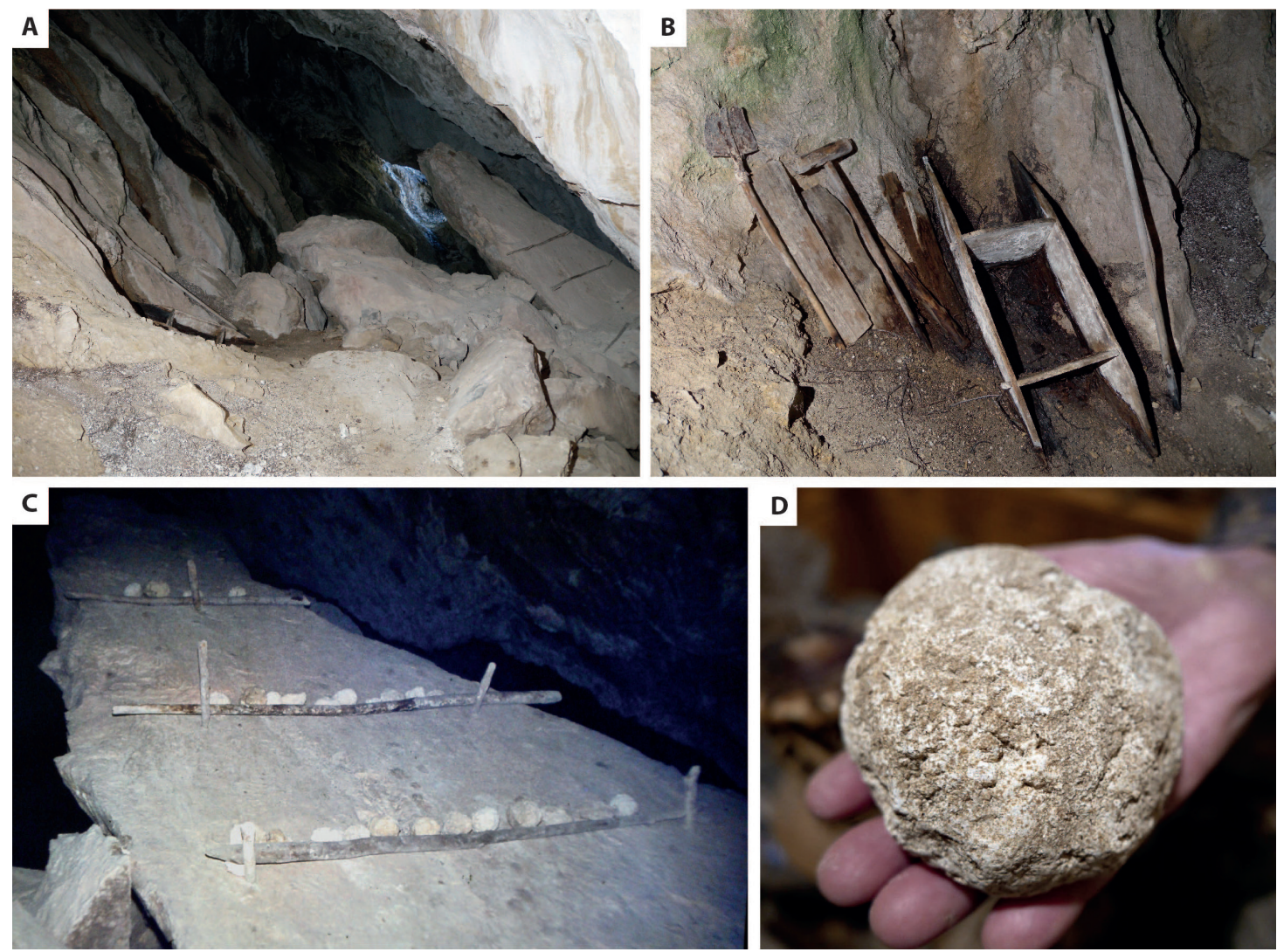

Fig. 5. A) View from the middle part of the cave towards the entrance. Wooden tools lean on the left slope and remains of the drying facility can be seen on the right side; B) Primitive tools left by the moonmilk miners; C) View of the drying facility showing a series of ball-shaped moonmilk chunks left by the miners. Width of image about $2 \mathrm{~m}$. Photograph taken in 1977 (courtesy G. Auer); D) One of the very few remaining (and meanwhile completely dehydrated) original moonmilk balls. 


\section{DISCUSSION AND CONCLUSIONS}

The picture that emerged from the study of Nixofen is in many ways consistent with the scattered and scarce information available from other sites in Austria:

- Extraction of moonmilk was common practice and the majority of these Nixbergwerke (17) existed in the eastern segment of the Northern Calcareous Alps (Fig. 1). Only one site is currently known in the southern part of Austria.

- All mines were small operations involving probably less than a handful of informed people.

- This artisan-type of mining used primitive, but nonetheless effective techniques of moonmilk extraction.

- The wet moonmilk had to be dried and this was accomplished by forming hand-sized balls and letting them dry on wooden racks. Interestingly, according to an old encyclopedia, Nihilum album (the true zinc oxide) was also sold as balls in past centuries (Hübner, 1721, p. 874).

- No official maps, reports or photographs exist about the work in these Nixbergwerke and all reports indicate that these activities were intentionally kept secret (e.g., Waldner, 1942, p. 2)

- As has been suggested previously (e.g., Topitz, 1974), experienced prospectors (termed Nixsucher or Nixgräber) apparently searched for moonmilk deposits in caves in the Eastern Alps and started these operations.

- Nixbergwerke were most likely worked during the snow-free season only.

- The timing of the onset of moonmilk mining in the Alps is still hidden in the darkness, but certainly goes back at least half a millennium (cf. Gesner, 1555). The oldest reliable report from Austria is one hundred years younger (Scheukofen, 1650).

- Nixbergwerke in Austria were in operation until the first half of the $20^{\text {th }}$ century. This is in contrast to Shaw (1992, p. 224) who concluded that the medical use of moonmilk ceased about the middle of the $18^{\text {th }}$ century in the western world. Due to the lack of historical data it can only be speculated that the abandonment of the Austrian sites was at least in part related to the advent of antibiotics, which are much more efficient than the previously used zinc oxide (and moonmilk).

- The use of moonmilk, however, was not restricted to human medical purposes; it was widely applied also to cure animal diseases. In addition, people used it for a variety of other purposes (e.g., Mattes, 2015, p. 108).

\section{OUTLOOK}

For a long time it has been supposed that dried moonmilk was used as an essentially illegal substitute for zinc oxide - with little or no pharmaceutical effect. Already Gesner (1555, p. 66) and later Kappeler (1767; reprint 1967; see also Jans, 1983) ridiculed that superstitious people use moonmilk to cure any sort of disease. On the other hand, the Swiss pharmacist
Sidler (1939/40, p. 228), who studied the use of moonmilk, concluded by quoting a local physician, Hans Portmann, that it would be interesting to examine moonmilk closely, because our ancestors were known to be sensitive observers.

Although quackery, superstition and placebo were certainly involved in the century-long business of moonmilk as a medical product, it is interesting to note that recent microbiological studies suggest that moonmilk might "effectively treat various infectious diseases thanks to the presence of a highly diverse population of prolific antimicrobial producing Streptomyces, and thus may indeed constitute a promising reservoir of potentially novel active natural compounds" (Maciejewska et al., 2016, p. 1-2).

\section{ACKNOWLEDGEMENTS}

I am grateful to the following colleagues for providing information and feedback: Georg Auer, Eckart Herrmann, Walter Klappacher, Günter Krejci, Rudolf Pavuza, Lukas Plan and Martin Trüssel. Gina Moseley kindly eliminated grammar mistakes. Two journal referees are thanked for their helpful comments.

\section{REFERENCES}

Barton H.A. \& Jurado V., 2007 - What's up down there? Microbial diversity in caves. Microbe, 2: 132-138. doi: https://www.asm.org/ccLibraryFiles/FILENAME/ 000000002921/znw00307000132.pdf

Binder H., 1963 - Gewinnung von Montmilch und Höhlendünger und andere Arten der Höhlennutzung in alter und neuer Zeit. Jahresheft der Karst- und Höhlenkunde, 4: 347-355.

Blyth A.J. \& Frisia S., 2008 - Molecular evidence for bacterial mediation of calcite formation in cold highaltitude caves. Geomicrobiology Journal, 25 (2): 101-111. https://doi.org/10.1080/01490450801934938

Borsato A., 1996 - Late-glacial to Holocene biogenic moonmilk and calcareous tufa deposits from caves in Trentino (NE-Italy): environment of precipitation and paleoclimatic significance. Il Quaternario, 9 (2): 473-480. http://www.aiqua.it/index.php/volume-9-2/604late-glacial-to-holocene-biogenic-moonmilk-andcalcareous-tufa-deposits-from-caves-in-trentino-neitaly-environment-of-precipitation-and-paleoclimaticsignificance/file

Borsato A., Frisia S., Jones B. \& Van der Borg K., 2000 Calcite moonmilk: crystal morphology and environment of formation in caves in the Italian Alps. Journal of Sedimentary Research, 70 (5): 1171-1182. https://doi.org/10.1306/032300701171

Cailleau G., Verrecchia E.P., Braissant O. \& Emmauel L., 2009 - The biogenic origin of needle fibre calcite. Sedimentology, 56 (6): 1858-1875.

https://doi.org/10.1111/j.1365-3091.2009.01060.x

Czoernig-Czernhausen W., 1926 - Die Höhlen des Landes Salzburg und seiner Grenzgebirge. Spelaeologische Monographien, 10: 1-159.

Engel A.S., Paoletti M.G., Beggio M., Dorgo L., Pamio A., Gomiero T., Furlan C., Brilli M., Dreon A.L., Bertoni R. \& Squartini A., 2013 - Comparative microbial community composition from secondary carbonate (moonmilk) deposits: implications for the Cansiliella servadeii cave hygropetric food web. International Journal of Speleology, 42: 181-192. https://doi.org/10.5038/1827-806X.42.3.2 
Gesner C., 1555 - Descriptio Montis Fracti sive Montis Pilati ut vulgo nominant, juxta Lucernam in Helvetia. Tiguri.

Gressel W., Hock R., Salzer H., Trimmel H. \& Vornatscher J., 1951 - Die wissenschaftliche Erforschung der Kreidelucke bei Hinterstoder im Toten Gebirge. II. Teil. Meteorologische Beobachtungen. Jahrbuch des Oberösterreichischen Musealvereins, 96: 227-251. http://www.zobodat.at/pdf/JOM 96 0227-0251.pdf

Hahnemann S., 1798 - Apothekerlexikon. Volume 2/1. Leipzig, Crusius.

http://www.zeno.org/Kulturgeschichte/M/ Hahnemann,+Samuel/Apothekerlexikon

Hartmann H. \& Hartmann W., 1985 - Die Höhlen Niederösterreichs (Vol. 3). Vienna (Landesverein für Höhlenkunde in Wien und Niederösterreich).

Hartmann H. \& Hartmann W., 1982 - Die Höhlen Niederösterreichs (Vol. 2). Vienna (Landesverein für Höhlenkunde in Wien und Niederösterreich).

Hauenschild G., 1866 - Weitere Beiträge zur Kenntnis der Kreidelucke im kleinen Priel. Jahrbuch des Oesterreichischen Alpen-Vereines, 2: 358-364.

Heller F., 1966 - Mondmilch oder Montmilch. Geologische Blätter für Nordost-Bayern, 16: 56-66.

Hill C. \& Forti P., 1997 - Cave Minerals of the World $\left(2^{\text {nd }}\right.$ ed.). National Speleological Society, Huntsville.

Hübner J., 1721 - Curieuses Natur=Kunst=Gewerk= und Handlungs-Lexicon. J.F. Gleditsch, Leipzig.

Ilming H., 1973 - Beobachtungen über Bergmilchabbau in der Hermannshöhle. Höhlenkundliche Mitteilungen, 29: 141.

Jäger G., 1873 - Der Wechsel und sein Gebiet in NiederOesterreich und Steiermark. IV. Von Kirchberg am Wechsel. Der Tourist, 5: 245-265.

http://digital.onb.ac.at/OnbViewer/viewer. faces?doc $=$ ABO_\%2BZ228219407

Jans V., 1983 - Das Mondmilchloch am Pilatus (Schweiz). Die Höhle, 34: 58-66.

http://www.zobodat.at/pdf/Hoehle_034_0058-0066.pdf

Kappeler M.A., 1960 - Pilatimonti historia. Naturgeschichte des Pilatusberges. Mitteilungen der Naturforschenden Gesellschaft Luzern, 18: 1-255.

http://doi.org/10.5169/seals-523466

Klappacher W., 1992 - Salzburger Höhlenbuch (Vol. 5). Salzburg (Landesverein für Höhlenkunde in Salzburg).

Klappacher W. \& Knapczyk H., 1979 - Salzburger Höhlenbuch (Vol. 3). Salzburg (Landesverein für Höhlenkunde in Salzburg).

Klappacher W. \& Knapczyk H., 1977 - Salzburger Höhlenbuch (Vol. 2). Salzburg (Landesverein für Höhlenkunde in Salzburg).

Kraus F., 1880 - Ueber alpine Höhlen. Jahrbuch des Oesterreichischen Touristen-Club, 11: 75-105.

Kraus F., 1894 - Höhlenkunde. Reprint 2009. Wissenschaftliches Beiheft Die Höhle, 56, Vienna (Verband Österreichischer Höhlenforscher).

Krejci G., Osl J. \& Kogler J., 1982 - Befahrung der Abendsteinhöhle und des Nixofens. Höhlenkundliche Mitteilungen des Landesvereins für Höhlenkunde in Tirol, 20: 8-9.

Kyrle G., 1923 - Grundriss der Theoretischen Speläologie. Vienna (Österreichische Staatsdruckerei).

Lonitzer A. (1578) - Kreuterbuch, künstliche Conterfeytunge der Bäume, Stauden, Hecken, Kräuter, Getreyd, Gewürtze etc. Franckfort.

http: / / daten.digitale-sammlungen.de/ db/0008/ bsb00086989/images $/$ index.html?seite $=00001 \& l=d e$

Maciejewska, M., Adam, D., Naômé, A., Loïc, M., Elodie, T., Całusińska, M., Delfosse, P., Hanikenne, M.,
Baurain, D., Compère, P., Carnol, M., Barton, H. \& Rigali, S., 2017 - Assessment of the potential role of Streptomyces in cave moonmilk formation. Frontiers in Microbiology, 8: 1181.

https://doi.org/10.3389/fmicb.2017.01181

Maciejewska M., Adam D., Loïc M., Naômé A., Całusińska M., Delfosse P., Carnol M., Barton H., A., Hayetten M.P., Smargiasso N., De Pauw E., Hanikenne M., Baurain D. \& Rigali S., 2016 - A phenotypic and genotypic analysis of the antimicrobial potential of cultivable Streptomyces isolated from cave moonmilk deposits. Frontiers in Microbiology, 7: 1455.

https://doi.org/10.3389/fmicb.2016.01455

Mattes J., 2015 - Reisen ins Unterirdische. Eine Kulturgeschichte der Höhlenforschung in Österreich bis in die Zwischenkriegszeit. Böhlau, Vienna, 410 p.

Moll F., 1839 - Handbuch der Pharmacologie, oder systematische Darstellung der Heilmittel (Vol. 1). A. Strauss, Vienna.

https://books.google.at/books/about/

Handbuch_der_Pharmacologie_oder_Systemat. html?id=uzBbAAAAcAAJ\&redir_esc $=y$

Mrkos H., 1997 - Erforschungs- und Erschließungsgeschichte der Hermannshöhle. In: Hartmann H., Hartmann W. \& Mrkos H. (Eds.), Die Hermannshöhle in Niederösterreich. Wissenschaftliche Beihefte Die Höhle, 50: 9-47.

Mutschlechner G., 1975 - Über Bergbau in Brandenberg. Tiroler Heimatblätter, 50: 127-129. Transcript: http://www.sagen.at/doku/bergbau/Bergbau Brandenberg.html

Padmavathy N. \& Vijayaraghavan R., 2008 - Enhanced bioactivity of $\mathrm{ZnO}$ nanoparticles-an antimicrobial study. Science and Technology of Advanced Materials, 9 (3): 035004.

https://doi.org/10.1088/1468-6996/9/3/035004

Reinbacher W.R., 1995 - Sprachliche Analyse des Ausdruckes "Mondmilch". Stalactit, 45: 18-23.

Reinbacher W.R., 1994 - Is it gnome, is it berg, is it mont, is it mond? An updated view of the origin and etymology of moonmilk. National Speleological Society Bulletin, 56: $1-13$.

Reiner J., 1857 - Ein Besuch der Nix-Höhle auf der Saualpe. Carinthia, 47: 145-146.

Reitschuler C., Spötl C., Hofmann K., Wagner A.O. \& Illmer P., 2016 - Archaeal distribution in moonmilk deposits from Alpine caves and their ecophysiological potential. Microbial Ecology, 71 (3): 686-699. https://doi.org/10.1007/s00248-015-0727-z

Reitschuler C., Lins P., Schwarzenauer T., Spötl C., Wagner A.O. \& Illmer P., 2015 - New undescribed lineages of non-extremophilic archaea form a homogeneous and dominant element within alpine moonmilk microbiomes. Geomicrobiology Journal, 32 (10): 890-902.

https://doi.org/10.1080/01490451.2015.1025317

Richter G.A., 1832 - Ausführliche Arzneimittelehre (Vol. 4). M. Lechner, Vienna.

https:/ / books.google.at/books?id=ClRcAAAAcAAJ\&pr intsec $=$ frontcover $\& h \mathrm{~h}=\mathrm{de} \# \mathrm{v}=$ onepage $\& \mathrm{q} \& \mathrm{f}=$ false

Richter D.K., Immenhauser A. \& Neuser R.D., 2008 Electron backscatter diffraction documents randomly oriented c-axes in moonmilk calcite fibres: evidence for biologically induced precipitation. Sedimentology, $\mathbf{5 5}$ (3): 487-497.

https://doi.org/10.1111/j.1365-3091.2007.00915.x

Rumpl L., 1962 - Linzer Preise und Löhne im 17. und 18. Jahrhundert. Jahrbuch des Oberösterreichischen Musealvereins, 107: 322-339.

http://www.zobodat.at/pdf/JOM 107 0322-0339.pdf 
Sawai J. \& Yoshikawa T., 2004 - Quantitative evaluation of antifungal activity of metallic oxide powders ( $\mathrm{MgO}$, $\mathrm{CaO}$ and $\mathrm{ZnO}$ ) by an indirect conductimetric assay. Journal of Applied Microbiology, 96 (4): 803-809. https://doi.org/10.1111/j.1365-2672.2004.02234.x

Sawai J., Igarashi H., Hashimoto A., Kokugan T. \& Shimizu M., 1995 - Evaluation of growth inhibitory effect of ceramics powder slurry on bacteria by conductance method. Journal of Chemical Engineering of Japan, 28 (3): 288-293.

https://doi.org/10.1252/jcej.28.288

Shaw T.R., 1992 - History of cave science. The exploration and study of limestone caves, to 1900 (2 $2^{\text {nd }}$ ed.). Sydney Speleological Society, New South Wales.

Sidler F., 1939-40 - Die Mandlimilch oder Mondmilch: ein altes Heilmittel. Schweizerisches Archiv für Volkskunde, 37: 218-228.

http://doi.org/10.5169/seals-113534
Topitz A., 1974 - Wie die „Nixhöhlen" zu ihrem Namen kamen. Oberösterreichische Heimatblätter, 28: 166-167. http://www.ooegeschichte.at/uploads/tx iafbibliografiedb/hbl1974_3_4_166-167.pdf

Trimmel H., 1968 - Höhlenkunde. Viewig, Braunschweig, $300 \mathrm{p}$.

Vierthaler F., 1816 - Meine Wanderungen durch Salzburg, Berchtesgaden und Österreich. Erser Theil. C. Gerold, Vienna.

https://books.google.at/books?id=EVhlAAAAcAAJ\&hl =de\&source=gbs_navlinks_s

Waldner F., 1942 - Nix und Nixhöhlen. Blätter für Naturkunde und Naturschutz, 29: 1-8.

https://www.zobodat.at/pdf/nat-land 19421 0001-0008.pdf

Weichenberger J. (2000) - Geschichten aus der Region des Nationalpark Kalkalpen, 260 p. http://wissensdatenbank.kalkalpen.at/Download. ash $x$ ?key $=8040$ 